\section{Expectations concerning retail: a study of clothing and shoe consumers at the bottom of the social pyramid}

\author{
Verner Luis Antoni \\ University of Passo Fundo, \\ School of Economic, Management and Accounting Sciences, \\ Master in Management, Passo Fundo, Brazil
}

\section{Kenny Basso}

IMED Business School, Master in Management,

\section{Passo Fundo, Brazil}

\begin{abstract}
Purpose - To understand different perceptions of retail by consumers at the bottom of the social pyramid, to thus understand specific market niches that are a part of the low income segment.

Design/methodology/approach - We carried out a survey including 560 cases. We also used cluster and discriminant analysis.

Findings - We observed the formation of four groups of customers, which showed significant distinctions in the characteristics considered for choosing a store.

Originality/value - The clusters represents a discriminant effort to highlight the differences between consumers considered in the same group of analysis, the bottom of the pyramid. Managerially, retail managers can assess their retail mix, and then drive more focused strategies and operations.
\end{abstract}

Keywords - Retail mix; retail; consumer behavior; low income.

Received on

06/24/2016

Approved on

$08 / 23 / 2016$

\section{Responsible editor:}

Prof. Dr. João Maurício Gama

Boaventura

Evaluation process:

Double Blind Review

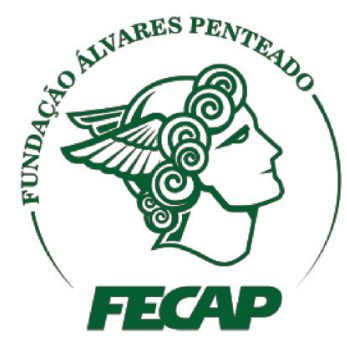

Review of Business Management 


\section{Introduction}

Low-income consumers at the bottom of the social pyramid have enormous consumption potential thanks to the large part of the population facing the possibility of gradual economic and social inclusion (Prahalad, 2010). This phenomenon was accentuated in face of economic stability in developing countries, arousing academic and business interest concerning this segment of consumers (Hemais, Borelli, Casotti, \& Dias, 2014). To Prahalad (2010), consumption at the bottom of the pyramid opens the path to improving the lives of the poor and eradicate world poverty, and, at the same time, it generates profits for companies, which run through the production and consumption focused on the bottom the pyramid.

Over the years, consumers at the bottom of the pyramid have begun to be recognized as individuals who are less dependent on society and governments, with their own expectations and consumption patterns, and thus have become an opportunity for businesses to expand their markets (Prahalad \& Hammond, 2002; Prahalad \& Hart, 2002; Prahalad, 2010). Specifically, these consumers have come to be understood in a different manner from the traditional economic and marketing point of view, raising the prospect that serving this class leads to a more inclusive practice of capitalism (Barros \& Rocha, 2009; Hemais et al., 2014). According to Prahalad (2010), the inclusion of these consumers in the consumer market causes the creation of new ways of offering and supplying the products created, since these consumers have characteristics and behaviors that can determine different choice patterns and purchasing decisions compared to wealthier consumers.

Limeira (2008) points out that South Africa, Argentina, Australia, Brazil, China, India, Mexico, Russia and Turkey are the countries that have the largest number of emerging consumers, which account for a $\$ 12.5$ trillion consumption potential market, greater than the sum of the markets of the major world powers of Germany, Italy, France, Japan and the UK. Observing this market, the reason why these countries and emerging markets attract investments from multinational companies is clear. Over the last decade, there was an increase in the low-income consumer market in Brazil (Costa \& Motta, 2015) and this national reality led to the production of various theoretical and empirical studies, with the most varied approaches regarding the "bottom of the pyramid or low-income" topic.

While studies advance, we see the need for a greater understanding of this sector and its relationship to consumption experiences, as well as the strategies and practices of companies producing goods and services aimed to this consumer group (Hemais et al., 2014). For companies operating in consumer markets, among which those that offer retail services, this consumer is an opportunity, but also a challenge, because according to Aguiar, Torres and Meirelles (2008), this segment presents behaviors, habits and aspirations that are different from higherincome consumers'. It is important to understand and investigate the cultural codes of low-income consumers, which fall on matters related to their hierarchy of spending and the meanings of brands for this group living within a specific cultural context (Barros \& Rocha, 2009).

Studies developed with the aim of broadening literature and understanding the development of strategies in low-income retail in emerging markets are still restricted, given the speed of change and sociocultural requirements of this consumer segment (Miotto \& Parente, 2015; Parente \& Barki, 2008). Studies have recognized and clustered retailers' strategies into groups regarding the format in which they offer their retail mix to low-income consumers. However, for Miotto and Parente (2015), these studies have only addressed suppliers' perspectives, and it is equally important to understand the specific perceptions and satisfactions of consumers in relation to strategies and retail formats offered to them, thus modernizing their sociocultural 
characteristics. Furthermore, these studies in the Brazilian context treat the bottom of the pyramid as a single class, however, it is believed that in such a vast class of consumers, different subgroups of consumers can be identified according to their preferences towards retail as a whole.

In this context, this study aims to identify the subgroups of consumers at the bottom of the Brazilian pyramid according to their expectations related to retail as a whole and clarify how such a compound is related to the average spending of the purchases made. Additionally, this phenomenon is analyzed based on the relationship with the limited budget, low status and self-esteem embedded in the act of buying, characteristics of the low-income consumption culture that have an impact on the choices and decisions of this group of consumers.

\section{Literature review}

\section{I Market and consumer culture characteristics at the bottom of the social pyramid}

Prahalad and Hammond (2002), Prahalad and Hart (2002) and Prahalad (2010) demonstrate the economic importance of the bottom of the social pyramid at a global level, and the need for organizations to understand their potential and especially, the characteristics of the consumers in this segment, to effectively serve them, since they differ from those located at the top of the pyramid.

Consumption oriented towards the bottom of the pyramid should be approached differently from the consumption directed to the upper classes, since an effective approach to these consumers goes through an innovative vision, without the repetition of old and worn solutions used in traditional markets. Moreover, universal or homogeneous solutions are not the best way to address these low-income markets, since each country in which this phenomenon occurs has its own cultural characteristics. Therefore, solutions must be segment-specific to the various segments at the bottom of the pyramid (Prahalad, 2010).
Prahalad and Hammond (2002) point to this segment as a great market opportunity, however, the authors highlight that large multinational companies should re-evaluate the relationship between the price and performance offered by their products and services, and promote radical technological innovations in their business models to meet these demands, generating local and not global solutions, which are offered to the high-income markets.

When Prahalad discusses a new perspective of low-income individuals in his studies, these individuals are seen as consumers, with desires to consume products of various kinds, bringing to light the gap left so far by marketing and economic thinking regarding low-income consumer (Hemais et al., 2014). In this sense, consumption becomes a form of social inclusion, not only by meeting needs and desires, in a utilitarian plan, but also by giving access to a symbolic universe in which belonging and identity rituals occurs (Rocha $\&$ Silva, 2009). According to Hemais et al. (2014), consumers at the bottom of the pyramid have begun to be understood, both by consumption researchers as well as by the market, as individuals who combine skills regarding consumer choices, such as the capability for analyzing and making the decision of where to buy, what to buy and how much they will spend; thus, these consumers are recognized as being aware of their actions and limits regarding consumption.

These consumers, according to Chauvel and Mattos (2008), co-exist in consumptionformation decisions with two rationales: one, material, which originates from the lack of resources, and imposes a strict rationalization of expenditures, and the other, symbolic, anchored in cultural elements and more specifically, in the relational and hierarchical dimensions of the Brazilian society.

Low-income consumers, on one hand, have the striking feature of the pursuit of economic rationality prevalent in their decisions, predominantly in their choices, since they face tough budgetary and financial constraints, and on 
the other hand, they express greater consumption desires, demonstrated through the possession of goods and services as alternatives for a better life. These higher levels of consumption desires are reflected in terms of quantity, quality and status associated with the goods consumed (Castilhos \& Rossi, 2009; Chauvel \& Mattos, 2008; Hemais et al., 2014). Following this thought, Pfeiffer and Maffezzolli (2011) found that the main reasons for purchase dissatisfaction of low-income consumers are faults or defects in the products and not the high price, which proves that low-income consumers do not care, necessarily, only about low prices, but also about the quality of products. Nevertheless, affordable prices also received great perceived importance in the study.

Furthermore, it should be understood that because these consumers have low incomes, they have low self-esteem, feel inferior and perceive that they are considered second-class citizens, which is worsened by the intense and camouflaged racial prejudice. This can be intensified and become a common strategic mistake when companies sell only second-line products, with low prices and restricted services, resembling a sense of consumer devaluation and promoting company's brand rejection (Parente \& Barki, 2008). In a study of low-income consumers who work as maids, Barros and Rocha (2009) found that, besides working, consuming is also a possibility for escaping poverty; being a consumer who buys "brands" emeregs as a much-desired alternative which provides these consumers with strong visibility in the social environment studied.

To organizations that serve low-income consumers, repeating strategies and actions that have been successful with higher-income individuals is a mistake, since decision-making regarding this public implies in understanding its characteristics, highlighting the need to demonstrate real concern towards this issue. Thus developing a standardized relationship is not enough. It is necessary to surpass the act of innovating, seeking to better understand the constraints and motivations of this group regarding consumption (Chauvel \& Suarez, 2009; Hemais et al., 2014; Parente \& Barki, 2008; Prahalad, 2010).
Given the tradition of indifference of businesses towards customer dissatisfaction, which is derived from the Brazilian historical context in which sellers were always privileged at the expense of buyers, low income consumers occupy a particularly weak position in Brazil, which changed with the increase of their income and purchasing power gained from the Real Plan, making them important consumers for businesses. However, these consumers have developed the idea that companies discriminate against them, treating them with less respect and consideration in comparison to the more wealthy consumers, and thus arising the challenge, set before organizations that want to build relationships with low-income consumers, of strengthening the perception of equity and fair treatment (Chauvel \& Smith, 2009).

Numerous studies at country level have dealt with the theme with different approaches in Brazil, such as: Araujo, Rocha, Chauvel and Schulze (2013), Brandão and Parente (2012), Parente, Brandão, Miotto and Plutarch (2012), Christopoulos and Ferreira (2012), Nogami, Vieira and Medeiros (2012), Nogami and Pacagnan (2011), Hemais et al. (2014), Neri (2010), Mattoso (2010), Barki and Parente (2010), Aguiar et al. (2008), Silva, Parente and Kato (2009), Castillos and Rossi (2009), Chauvel and Mattos (2008), Limeira (2008), Parente and Barki (2008) Parente, Barki and Kato (2005). These studies, based on different theoretical and empirical perspectives, have addressed issues relating to the scope, the size and the importance of this market, which resulted in reviews of studies and academic findings on the subject, proposing classifications, clusters and segmentations, discussing purchase behavior, the meaning of leisure for low-income consumers, strategic marketing and its managerial implications in organizations.

To Nogami and Pacagnan (2011), although late, the subject of consumers at the bottom of the pyramid is now a reality in Brazil, presenting many challenges to be overcome; thus, further investigation and a greater amount of research must be carried out so that the concept 
can be expanded and qualified. Hemais et al. (2014) indicate the need to open more space for marketing studies to be conducted on both this segment and its relation to the consumption experiences, as well as the practice of companies producing goods and services targeting this audience, and moreover why the consumer at the bottom of the pyramid have become the focus of academic and business interest, with the promise that these consumers will sustain the economic and global growth.

\subsection{Retail mix for the bottom of the pyramid}

For retailers to succeed in their role of serving end consumers, it is necessary to understand the evaluation criteria, the appropriate characteristics for point of sale and the comparative processes and criteria that consumers consider acceptable or unacceptable to meet their expectations. Based on this understanding of the consumers, it is possible to set the retail mix to be offered to the market, which should be consistent with buyers' demands (Cotlier, 2003; Hooley, Saunders \& Piercy, 2005).

The retail compound, according to Parente and Barki (2008), encompasses all controllable factors articulated by the retailer, which are: the mix of products, prices, promotions, presentation, staff and the point of sale. Table 1 lists these variables and gives examples of decisions that retailers makes to present differentiation in the market.

\section{Table 1}

\section{Retail mix - the 6 Ps}

\begin{tabular}{ll}
\hline Retail composite variables & Example of decisions \\
\hline Products Mix & Variety in the product line, quality, services \\
Prices & Price, credit, deadlines \\
Promotion & Advertising, offers, signaling \\
Presentation & Store, departmentalization, planogram \\
Personnel & Service, speed \\
Point of sale & Location, access \\
\hline
\end{tabular}

Source: Adapted from "Retail value directed to the low income segment" of G. J. Parente, E. Barki. In J. G. Parente, T. M. V. Limeira, \& E. Barki (Eds.), 2008, Retails for low-income. Porto Alegre: Bookman.

Considering retailers' strategy regarding building value for low-income consumers, Parente and Barki (2006) identified three prevailing strategies in this market regarding the retail mix: the first is called the low-price emphasis, a strategy adopted by companies that operate with competitive prices and lower investment. This strategy is characterized by a lower value regarding other aspects of the retail mix, by providing products, services and store environment with lower added value. Another strategy is benefit-emphasis, which focuses on an attractive package of benefits, with good service, a good range of products and nice facilities. Finally, proximity-emphasis strategy is adopted by the companies that build a value proposition based on physical proximity and a closer relationship with the customer, which is perceived through a more personalized service, a location closer to the customers and credit facility.

Price is a key aspect in the market insertion strategy of retailers that direct their positioning to the low-income public. Therefore, low prices for purchases in cash, good payment deadlines and small installment payments so that the consumer can pay their debts, are premises to operate in this market (Nogami, Vieira, \& Medeiros 2012). In this context, the credit policy is perceived as a hierarchical element, assuming the category of status symbol and a source of identity (Mattoso 
\& Rocha, 2009). However, it is a myth to think that these consumers essentially prefer the stores that only offer low prices (Parente \& Barki, 2006), especially since strategies with an emphasis on price ignore the importance of other retail mix elements, thus reducing value perception of retail brands, and possibly increasing the feeling of low self-esteem and the feeling of marginalization perceived by this group of consumers.

D'Andre, Ring, Aleman and Stengel (2006) point out that a failure of large companies is to simply transfer a product originally positioned for high-income consumers for the customers at the bottom of the pyramid, since these products must meet the expectations of this audience. Parente and Barki (2006) emphasize the importance of product category management, demonstrating that the product mix must balance leading brands and inferior products. Therefore, it is a mistake to think that the consumer is not loyal to brands or prefers second-line products. Also, it should be highlighted that due to the desire for brands and the restrictions imposed by their budgets, consumers use brand alternation and the situational use of products as a strategy to reduce their constraints (Costa \& Motta, 2015). Companies must reconcile consumers' desire regarding the leading brands with their budgetary constraints, allowing this segment to access these categories of products and brands (Araujo \& Adler, 2015).

Regarding the service, the staff and the store environment are differentiating elements of the retail mix for this audience, since these are consumers with low education and low selfesteem, which leads them to value sociability and signals that avoid the feeling of distrust on them. Employee training should lead employees to face to a face contact, courteous and respectful service, and willingness to answer questions and explain about the products and services in the store. All these aspects must also be associated with additional services related to payment, home delivery and parking, attitudes that add value to the bottom of the pyramid. The store environment and the advertising should avoid giving the impression of disinterest, distrust and sadness, so as to avoid enhancing consumers' low self-esteem, which impacts the trust relationship with the store (Nogami, Vieira, \& Medeiros, 2012; Parente \& Barki, 2008).

As for the location of the store, physical proximity to the consumer at the bottom of the pyramid is a decisive factor for the selection of a point of sale, because the consumer includes in the purchase cost the effort and financial expense of the dislocation (Parente \& Barki, 2008). Communication influences this consumer by using sound cars, billboards, bus door and metro door signs, the two last forms are considered to be very effective due to the fact that the consumer often uses public transportation (Vieira, Maia, \& Silva, 2010; Nogami, Vieira, \& Medeiros, 2012).

The store environment and its merchandising should be presented in bright colors, strong lighting, plenty of products on display, clarity and simplicity in communication, bold letters and highlighting in signaling low prices, large quantities and a variety of products, since these consumers enjoy abundance and do not care so much about visual pollution (Nogami, Vieira, \& Medeiros, 2012; Vieira et al., 2010; Parente \& Barki, 2008).

Considering the description of the retail mix, it appears that low-income consumers are not influenced only by low price policies and easy credit, but also choose the points of sale based on a value equation that considers tangible and intangible aspects of the marketing retail mix. As such, the best strategy for retailers is linked to the understanding of the characteristics and behavior of this group of consumers, and also to a compound that reflects in a better value equation for the market.

\section{Method}

To meet the objective of the study, a quantitative-descriptive research was conducted through a survey enabled clustering the consumers in groups, considering their perceptions the dominant characteristics of the retail mix.

The study sample was composed of lowincome consumers who were in the purchase 
process in clothing and shoe stores. The sampling technique occurred by convenience, that is, the researchers approached and invited the consumers to participate in the survey as they were leaving the stores, after these had made their purchases. The final sample included 560 respondents.

The stores were identified by a previous exploratory survey with fifty low-income consumers belonging to the population researched. This study also provided the basis for the preparation of instrument for data collection and to support the interpretation of the result categories.

The study took place in nine cities (Cruz Alta, Ijuí, Giruá, Panambi, Santa Rosa, Santo Antônio das Missōes, Santo Ângelo, São Borja and São Luiz Gonzaga) located in the Northwestern and Missóes regions of the state of Rio Grande do Sul, Brazil. Between 36 and 84 cases were collected in each city. It is important to highlight that none of the cities is recognized as footwear production or retailing hub, which could lead to different consumer behaviors. Moreover, there is, in these cities, a great difference between the consumption of low-income and the consumption of the middle and upper classes.

The criteria used to classify the lowincome consumers was the Brazilian Economic Classification Criterion of the Brazilian Association of Research Companies (ABEP, 2012), which is consolidated from the IBGE indicators. According to this criterion, individuals with a family income up to $\mathrm{R} \$ 1,459.00$ or less are classified in classes $\mathrm{C}, \mathrm{D}$ or $\mathrm{E}$, according to their income range.

The questionnaire used in the survey was based on the literature mentioned in this article and on the indicators from the exploratory stage, previously mentioned. To measure the perceived importance in the retail mix characteristics, a multiple-choice question asked which were the three retail mix characteristics considered to be decisive in the choice of one store over another. This question had eight alternatives as possible answers, namely: location of the store, variety and quality of the products and brands, staff service and store services, price, promotions, confidence in the store, store environment, store installment payment options.
Then, the consumers were questioned about their media preferences, payment options, purchase dates and days for clothing and footwear purchases. To check the average value of purchases made, the value of the last purchase made by the respondent was requested. Finally, the instrument asked demographic questions to characterize the respondents.

Data collection occurred "in loco" after consumers made purchases in women's clothing and shoe stores, for low-income brands, in the cities cited as the geographical scope of the study. Data collection was carried out by researchers specially trained and prepared for this research.

During the database treatment and organization of the variables, no missing values were identified and no differences were found in the variables when analyzed between the municipalities in the sample $(p>.10)$, a result that allowed for grouping the cases into a single sample.

For the data analysis, the answers to the multiple choice question about the importance of the retail mix characteristics were converted into new dummy type variables, which were used in the discriminant analysis that enabled clustering. Given the purpose of the study was to identify subgroups that make up the low-income segment, we opted for the cluster analysis since it is indicated for classifying heterogeneous samples of individuals, forming relatively homogeneous groups (Hair, Anderson, Tatham \& Black, 2005). Cluster analysis was performed using Ward's method as a hierarchical clustering procedure, which according to Hair et al. (2005) treats the distance between two clusters based on all the variables involved. The Euclidean squared distance was used as measure, which is the recommended type of measure to be used with Ward's method (Hair et al., 2005).

After the cluster analysis, a discriminant analysis was carried out to check the quality of the groups created. Therefore, discriminant analysis, performed by canonical correlation, aimed to test for the quality of the cluster solution found and the explanatory power of each feature of the marketing mix on the classification of the clusters. 


\section{Results and discussion}

\section{I Sample characterization}

Demographic and behavioral segmentation variables were used to characterize the sample (Peter \& Olson, 2009). Regarding the demographic variables, only female subjects were surveyed in this study, with a mean age of 33.9 years ( $\sigma=14.11$ years). Most subjects had complete high school education or incomplete higher education (39.6\%), followed by those who had full elementary education or incomplete high school education (24.6\%).

The income level and social class, shown in Table 2, are predominantly within the $\mathrm{C} 1$ and $\mathrm{C} 2$ classes, followed by D and E classes.

\section{Table 2}

\section{Income range and social class of the sample}

\begin{tabular}{lcc}
\hline $\begin{array}{l}\text { Income } \\
\text { range }(\mathbf{R} \$)\end{array}$ & Social class & $\begin{array}{c}\text { Participation } \\
\text { in the sample (\%) }\end{array}$ \\
\hline $1,459.00$ & $\mathrm{C} 1$ & 47.0 \\
962.00 & $\mathrm{C} 2$ & 26.8 \\
680.00 & $\mathrm{D}$ & 14.1 \\
415.00 & $\mathrm{E}$ & 12.1 \\
\hline
\end{tabular}

As for behavioral characteristics, most interviewees preferred to receive retailer advertisement through pamphlets (47.5\%), TV $(44.6 \%)$, radio $(35.6 \%)$ or booklets $(33.4 \%)$. As for the form of payment, the subjects reported that the payment by payment installments $(57.9 \%)$ is the most widely adopted method, followed by cash $(23.8 \%)$ and credit cards (10.5\%). The interviewees tend to go shopping, on average once a month $(47.5 \%)$ or when there is season change (27.7\%). Saturdays (49.3\%) and Fridays (25.9 $\%)$ are preferred days for this activity. Average spending on purchases was R $201.00(\sigma=R$ \$ 115.86) per store purchase.

\subsection{Configuration of the clusters}

Four distinct clusters were identified regarding retail mix characteristics. It is worth noting that it took six iterations for this fourcluster solution to be found. Alternative solutions with fewer clusters (2 and 3) and more clusters (5 and 6) were also tested; however, the fourcluster solution was the best for discriminating the subgroups. Moreover, this solution was also adopted based on the between-group distinction, which presents important theoretical and practical relevance for this study. The results for cluster analysis are presented in Table 3, wherein all the retail mix characteristics are described.

Table 3

Cluster analysis

\begin{tabular}{|c|c|c|c|c|c|c|c|}
\hline \multirow[b]{2}{*}{ Retail characteristic } & \multicolumn{4}{|c|}{$\%$ of Importance of the characteristic } & \multirow[b]{2}{*}{$\chi^{2}$} & \multirow[b]{2}{*}{ DF } & \multirow[b]{2}{*}{$p$} \\
\hline & $\begin{array}{l}\text { Cluster } 1 \\
\text { - SP }\end{array}$ & $\begin{array}{l}\text { Cluster } 2 \text { - } \\
\text { PP }\end{array}$ & $\begin{array}{c}\text { Cluster } \\
3-\mathbf{R}\end{array}$ & $\begin{array}{l}\text { Cluster } 4 \text { - } \\
\text { SPP }\end{array}$ & & & \\
\hline Store Location (Point of sale) & 15.1 & 23.5 & 6.1 & 0 & 31.19 & 3 & $<0.001$ \\
\hline $\begin{array}{l}\text { Variety and quality of products and brands } \\
\text { (Product mix) }\end{array}$ & 36.3 & 64.3 & 38.4 & 100 & 126.99 & 3 & $<0.001$ \\
\hline Staff Service and Store Services (Personnel) & 93.6 & 0.9 & 75.8 & 100 & 388.69 & 3 & $<0.001$ \\
\hline Price (Price) & 51.0 & 77.4 & 37.4 & 100 & 108.50 & 3 & $<0.001$ \\
\hline Promotions (Offers) & 38.6 & 4.3 & 10.1 & 0 & 81.63 & 3 & $<0.001$ \\
\hline Confidence in the store (Staff) & 0 & 11.3 & 100 & 0 & 487.93 & 3 & $<0.001$ \\
\hline Store environment (Presentation) & 12.4 & 13.9 & 4.0 & 0 & 18.98 & 3 & $<0.001$ \\
\hline Store installment payment plans (Price) & 52.6 & 67.0 & 27.3 & 0 & 118.45 & 3 & $<0.001$ \\
\hline $\mathrm{N}$ & 251 & 115 & 99 & 95 & - & - & - \\
\hline
\end{tabular}

Obs. The table lists the definition of mix of retail consisting of consumers surveyed and the definition of Parente and Barki 2008. Adapted from "Value retail directed to low-income segment" of G. J. Parente, E. Barki. In J. Parente G., T. M. V. Limeira, \& E. Barki (Eds.), 2008, retails for the low income. Porto Alegre: Bookman. 
As shown in Table 3, the cluster analysis found the best solution through the formation of four sets of subjects, called: Service-Price (SP), Price-Product (PP), Relational (R), ServiceProduct-Price (SPP).

In the first cluster (SP), the staff service and the services offered by the store, credit options and price are the three most representative characteristics in determining the choice of the store. Understanding the staff service and store services offered, as was defined in the exploratory stage, refers to the behavior of both the sellers and the store staff, which is evaluated through aspects such as good mood, sympathy and attention, in addition to these aspects, queuing time, the number of cashiers available and the ease of product exchange were evaluated. Credit is perceived through payment deadline, the amount of available payment installments and the flexibility and ease in negotiating product purchase. The price, in turn, refers to the perceived fairness in the offers and the ease of negotiating them. Regarding the media used to recognize the retailer, there is a preference for TV, booklets and radio. The average amount spent by individuals on their purchases is R\$202.01.

When the second cluster (PP) was analyzed, price and payment options exerted great influence on store selection. These criteria were followed by product variety and the quality of the products offered. As defined by consumers in the exploratory stage of the study, product variety and product quality are perceived through the amount of products and brands available at the store, the comfort and the durability of the products and also by the presence of brands known by consumers. TV, radio and pamphlets were the preferred means for store communication with the consumers. This group was the one with the lowest average purchase spending $(M=\mathrm{R} \$ 171.73)$.

In the PP and SP clusters, the importance of installment payment options and low price was observed, which is perceived as offer "fairness", and must be associated with the ease in negotiating the purchase in cash or with deadlines and small installments, which the consumer is able to meet. These are premises to operate in this market, as indicated by Nogami, Vieira and Medeiros (2011). This approach is consistent with Mattoso and Rocha (2009), who consider the credit policy as a status symbol for these consumers, emerging as a social hierarchy element and therefore as a source of identity, since this consumer has the strong cultural trait of feeling marginalized and, also, of having low self-esteem due to belonging to the poorest layers of the population.

Despite the importance of price and credit, Parente and Barki (2008) highlight that one must be careful, when the offer is based solely on low prices, the strategy named by the authors as low price emphasis, which is commonly adopted by retailers that operate in the consumer segment under study and ignore other retail mix elements. This strategy can reduce consumers' perceived value, increasing their sense of low self-esteem and marginalization, leading them to reject brands of retailers who operate in this format.

Consumers grouped in the third cluster (R) indicated that the main factor for choosing a store is trust $(100 \%)$, followed by staff service and the services offered by the store. Trust, in turn, is perceived by the interviewees, as was pointed out in the exploratory stage, through the honesty conveyed by the employees and the company management, by the fulfillment of the offers communicated and also the reliability transmitted by the products and brands marketed. It is noted that the confidence for these consumers is formed by both cognitive (promise fulfillment and product and brand perceived reliability) and by affective aspects (honesty perceived in the employees and in the managers). This approach of affective and cognitive precedents is found in the literature on trust by Johnson and Grayson (2005) and Terres, Santos and Basso (2015). In addition to the influence of these variables on choice, consumers prefer information from TV and pamphlets. The average amount spent on purchases is R\$216.14. 
Finally, in the fourth cluster (SPP), consumers highlighted staff service and services offered by the store, the variety and product quality and prices as aspects analyzed to choose the store. It should be noted that in this cluster, the choice for the three retail mix characteristics was unanimous. That is, other attributes were not mentioned. These consumers consider TV and pamphlets as the most attractive media. In this cluster, the highest purchases average value was identified as ( $M=\mathrm{R} \$ 217.99)$.

Regarding the differences in the average spending of each purchase, Clusters $1(M=$ $\mathrm{R} \$ 202.01), 3(M=\mathrm{R} \$ 216.14)$ and $4(M=\mathrm{R} \$$ 217.99) had similar means. However, Cluster 2 showed a significantly lower average spending ( $p$ $<0.05)$ than the average presented by the other groups $(M=\mathrm{R} \$ 171.73)$, revealing an important distinction in this cluster. It should be noted that this group pays special attention to the cognitive aspects and focuses on price, while other customer groups focus their attention on elements related to the relationship with the service provider, which can, in turn, add value and provide a higher average ticket.

\subsection{Discriminant analysis}

To analyze the distinction between the clusters found, that is, if the clusters presented significant differences and where such differences were located, a discriminant analysis was performed (Morrison, 1969). This analysis was performed using the input method for variable inclusion in the functions, i.e. all the variables (retail mix characteristics) were included together and at the same time in the preparation of the discriminant functions.

In order to verify the explanation that the calculated functions have, Table 4 presents the results of the canonical correlation, which is a measure of association between the groups (clusters) and the associated discriminant function, used to analyze the explanatory power that independent variables presented (retail mix) on the dependent variable (clusters).

\section{Table 4}

\section{Canonical correlation}

\begin{tabular}{lcccc}
\hline Function & Eigen value & Variance $\%$ & Cumulative \% & Canonical correlation \\
\hline 1 & 7.54 & 67.0 & 67.0 & 0.94 \\
2 & 2.71 & 24.1 & 91.1 & 0.85 \\
3 & 1.00 & 8.9 & 100.0 & 0.70 \\
\hline
\end{tabular}

Based on Table 4, founded on the data obtained from the canonical correlation of function 1, it was established that this function explains $88.3 \%\left(0.94^{2}\right)$ of the variance. Function 2 explains $72.2 \%\left(0.85^{2}\right)$ of the remaining variance, i.e., $72.2 \%$ of $11.7 \%$ which is $8.44 \%$. Finally, the third function explains $49.0 \%\left(0.70^{2}\right)$ of the remaining variance of the sum of the variance explained by the two first functions, that is, $49.0 \%$ of $3.26 \%$, which is $1.59 \%$. In this way, the total variance of the dependent variable (cluster) explained by the three discriminant functions is equal to $98.33 \%(88.3+8.44+$ 1.59). This result shows the strong discriminant power of the retail mix characteristics for the four clusters found. In general, the retail mix components explain $98.33 \%$ of the variations found in the clusters. This result allows us to infer that such marketing variables can be used to classify subgroups belonging to the bottom of the social pyramid.

Regarding individuals' classification observed in the discriminant analysis, the solution found was responsible for the correct categorization of $94.8 \%$ of the cases in their original groups, based on the retail mix characteristics preferred by each group of consumers. It is important to highlight that the validation of the classification was made by cross-classification, which obtained a $94.8 \%$ rate of correct classifications, indicating the robustness of the original classification found. Table 5 shows the classification found. 
Table 5

Case classification

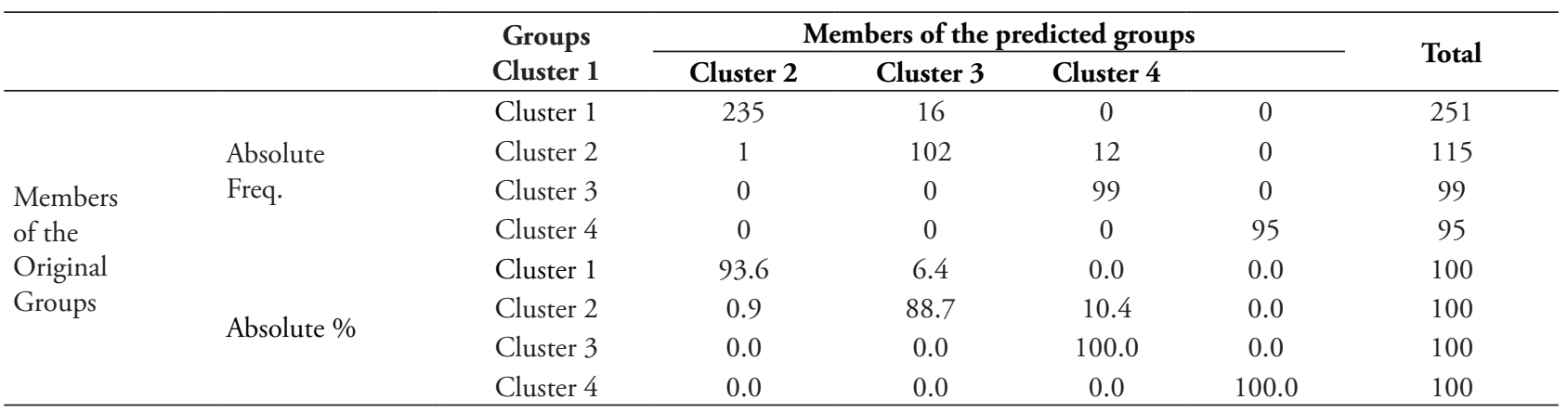

In addition, Press' $Q$ calculated test (1456.01) was greater than the value of 6.63 ( $p=$ $0.001)$, indicating that the classification power found is different from the classifications made at random. Individually, all groups had similar correct classifications (ranging from $88.7 \%$ to $100.0 \%$ ).

With the classification of the consumers studied, the possibility of differences between the variables of demographic and behavioral segmentation among the groups was verified. Thus, listing the demographic variables used, it was verified if, among the groups, there were differences in the level of education, the family income and the age of the respondents. The results showed that the level of education was not different between the groups of consumers $\left(\chi^{2}=14.375, \mathrm{df}=12 ; p=0.277\right)$, and the main level of education was complete high school/incomplete higher education, ranging from $36.4 \%$ to $46.1 \%$ of respondents in each group. While this paper addresses the bottom of the pyramid, there is a division between four income groups and social classes $(\mathrm{C} 1, \mathrm{C} 2, \mathrm{D}$ and E). However no difference in the distribution of income between groups was found $\left(\chi^{2}=4.323\right.$, $\mathrm{df}=9 ; p=.889)$. Finally, age presented a significant difference between groups $(F(3,555)=2.617$; $p=0.05)$, and the Clusters $4(M=36.06), 1(M$ $=34.50)$ and $3(M=34.08)$ showed a significant mean age higher than the average presented by the subjects within Cluster $2(M=30.94)$.

Regarding the possible behavioral differences, results show that, among the groups, distinctions were not found regarding the preferred forms of payment $\left(\chi^{2}=16.715, \mathrm{df}=18\right.$; $p=0.543)$; purchase frequency $\left(\chi^{2}=10.355 ; \mathrm{df}=12\right.$; $p=0.585)$; preference for the day of the week $\left(\chi^{2}=24.549, \mathrm{df}=21 ; p=0.267\right)$; the time preferred for shopping $(F(3,556)=0.157 ; p=0.925)$; and the average time spent shopping $(F(3$, 556) $=1.697 ; p=0.167$ ). However, two variables showed significant differences between the groups, namely: the type of media preferred to learn about retailers $\left(\chi^{2}=54.206, \mathrm{df}=27 ; p<0.001\right)$ and the average spending on purchases $(F(3,556)=3.751$; $p<0.05)$. Table 6 presents the media preferences of each cluster.

\section{Table 6}

\section{Cluster analysis}

\begin{tabular}{lcccc}
\hline \multirow{2}{*}{ Retail characteristic } & \multicolumn{3}{c}{ \% Frequency } \\
\cline { 2 - 5 } & Cluster 1 & Cluster 2 & Cluster 3 & Cluster 4 \\
\hline Pamphlets & 42.3 & 47.8 & 50.5 & 57.4 \\
TV & 39.5 & 50.4 & 50.5 & 44.7 \\
Radio & 37.1 & 40.0 & 34.0 & 27.7 \\
Booklet & 38.7 & 26.1 & 24.7 & 37.2 \\
Sound car & 19.0 & 20.9 & 9.3 & 11.7 \\
Newspaper & 10.9 & 14.8 & 16.5 & 13.8 \\
Email & 3.2 & 0.9 & 8.2 & 2,1 \\
Billboards & 2.4 & 4.3 & 6.2 & 0.0 \\
SMS & 2.0 & 2.6 & 1.0 & 3.2 \\
\hline
\end{tabular}

Note: The percentages total over $100 \%$ due to the possibility of multiple choices. 
In Table 6 it is possible to observe that Cluster 1 shows a stronger preference for pamphlets (42.3\%), as well as Cluster 4 (57.4\%), while Cluster 2 showed a stronger preference for TV (50.4\%) and Cluster 3 showed a similar preference between TV and pamphlets (50.5\% each).

\section{Final considerations}

The study identified that clothing and shoe retail consumers belonging to the bottom of the pyramid can be classified and grouped according to their preferences for retailer selection. Specifically, this study showed that a solution of four clusters can be formed to successfully classify (94.8\% correct classifications) individuals in the researched group that form the bottom of the Brazilian pyramid.

In general, in accordance with the results of the cluster analysis and in line with the proposed by Parente and Barki (2008), in the segment at the bottom of the pyramid, sub segments can be found. These groups, in addition to presenting a relative importance to the price variable, also consider other variables from the marketing mix relevant. With the exception of the PP cluster, the combination of staff service and level of store service with other elements of the retail mix, other than price, is considered crucial to the choice of a store, as indicated by Parente and Barki (2008), D'Andre et al. (2006), Parente et al. (2012), and Nogami et al. (2012).

Clearly, in the composition of the SP, R and SPP clusters, which have a value equation supported by elements other than price of the retail mix, the average purchase value is higher. This behavior can be explained by the fact that consumers seek a balance between their budgetary constraints and the desire for high consumption, which is carried out by the possession of goods and services that may reflect on quality and status on the goods consumed, as shown by Chauvel and Mattos (2008) and Pfeiffer and Maffezzolli (2011). These consumers like to be treated well, which may be related to the fact that lowerincome consumers feel discriminated and even deceived by the companies in comparison to higher-income consumers (Chauvel \& Smith, 2009), leading them to seek equity and fairness in treatment. This leads to stating that when companies manage to reverse this thought, they are able to generate high levels of satisfaction and achieve the benefit of brand loyalty.

The importance of low-income consumers cultural characteristics related to self-esteem and distrust are also noteworthy and are brought to attention by Aguiar et al. (2008). It is also important to highlight regarding Cluster $\mathrm{R}$ that when consumers perceive actions like honesty from the employees and the management, promise fulfillment regarding what was advertised and reliability of the products and brands marketed, consumers can experience increased self-esteem and a distrust reduction towards the brand.

The amount of products and brands available at the store (PP and SPP clusters), associated with quality may refer to a concept of abundance, which is an important attribute in these consumers' perspective. The acquisition of products brings a sense of status, which can make consumption a form of social inclusion (Rocha \& Silva, 2010), also bringing a balance to the symbolic perspective of social belonging, rooted in cultural elements and the relational and hierarchical dimensions of the Brazilian society (Chauvel \& Mattos, 2008 ). Product category management with leading brands and inferior products is important for low-income consumers. Thus the thought that low-income consumers prefer second-line products is a mistake (Parente $\&$ Barki, 2008). At the same time, low-income consumers use the brand alternation strategy and situational use to overcome the restrictions imposed by their budgetary constraints according to their financial condition (Costa \& Motta, 2015), reinforcing the importance of maintaining a product mix that balances quantity, quality and variety of products and brands, as identified by the study.

Location was not considered an important factor for store selection by the subjects that 
comprised the clusters. Thus, future studies can better explore how location influences this segment of customers in their retail choice. It is relevant to highlight that Barki (2005) indicates location as an attribute of extreme importance to consumers at the bottom of the pyramid.

The results of this article present both academic and managerial implications. Academically, it is believed that this work represents an effort to research a phenomenon that deserves further development for a better understanding of the purchase and consumption behavior of the bottom of the pyramid in Brazil. As highlighted by Prahalad and Hammond (2002), Prahalad and Hart (2002) and Prahalad (2010), knowing the capabilities of the bottom of the pyramid for the world market, in any context, should begin with an understanding of the main characteristics, behaviors and attitudes that differ this consumer group from other groups previously studied. Therefore, the use of the cluster and the discriminant analysis may be important to generate knowledge about the specificities of these consumers.

The clusters generated in this study represent a discriminant effort to highlight the differences between consumers so far considered under the same scope of analysis, known as the bottom of the pyramid. New studies may test the empirical classification suggested in this article and increase knowledge about these individuals. Possible insights may involve the study of consumption characteristics, wealth, formation of their cultural capital and even the personality of these individuals.

According to D'Andre et al. (2006), it is common for companies to use the same marketing mix and strategies developed for the high-income public with the low-income public. However, as this study shows, even within the low-income, there are different behaviors, preferences and expectations that can be identified and better addressed. In this sense, future studies could not only address research topics related to the bottom of the pyramid, but could also address the understanding of the complexity and the differences among consumers of the studied class.

Managerially, the results presented in this study can provide retail managers with information to assess their retail mix in relation to the characteristics of the public that they service. Moreover, managers can direct their strategies and operations more effectively, aiming to increase the power of attraction for possibly retaining these customers and achieving higher sales volume.

Although this study contributes to the advancement of academic and applied discussions about the bottom of the pyramid, certain limitations require caution to the reader and suggest new routes for future researchers. First, this study is limited by its geographical extent, although several municipalities were included for data collection, it is believed that even greater differences may occur in behaviors if other regions of Rio Grande do Sul and/or other states are included. Thus, it is suggested that further studies apply the methodology and compare the groups found with others to be formed in different states and contexts.

Regarding the context of application, by using women's clothing and shoes retail, this study is limited to the influence of the characteristics of this type of retail for choosing a store. Thus, it is suggested that further studies choose other retail segments to identify possible differences in the influence of the retail mix characteristics for choosing a store. Finally, by only considering female consumers, this study enhances the understanding and discrimination through cluster analysis. However, this choice implies a limitation for the generalization of the findings towards male individuals. Thus, researchers are suggested to further enhance the knowledge by comparing the behaviors and the clusters formed between individuals of different genders, with the aim to understand possible influences and differences caused by gender. 


\section{References}

Associação Brasileira de Empresas de Pesquisa. (2012). Critério de Classificação Econômica Brasil. Recuperado de http://www.abep.org/novo/ Content.aspx?ContentID=301

Aguiar, L., Torres, G. de H., \& Meirelles, R. (2008). O consumidor de baixa renda. In J. Parente, T. M. V. Limeira, \& E. Barki (Orgs.), Varejo para a baixa renda (pp. 13-31). Porto Alegre: Bookman.

Araujo, F. F., \& Adler, L. B. (2015). O Lançamento de uma nova embalagem do refrigerante CocaCola: Um estudo de caso sobre o lançamento da mini pet pela empresa Rio de Janeiro Refrescos. Revista Pensamento Contemporâneo em Administração, 9(2), 113-128.

Araujo, F. F., Rocha, A., Chauvel, M. A., \& Schulze, M. (2013). Meanings of leisure among Young consumers of a Rio de Janeiro low-income community. Leisure Studies, 32(3), 314-332.

Barki, E. (2005). Estratégias de empresas varejistas direcionadas para a baixa renda: Um estudo exploratório. (Dissertação de Mestrado). Escola de Administração de Empresas de São Paulo da Fundação Getúlio Vargas, São Paulo, SP, Brasil.

Barki, E., \& Parente, J. G. (2010). Consumer behaviour of the base of the pyramid market in Brazil. Greener Management International, (56), 11-23.

Barros, C., \& Rocha, E. (2009). Lógica de consumo em um grupo das camadas populares: Uma visão antropológica de significados culturais. In A. da Rocha, \& J. F. Silva (Orgs.), Consumo na Base da Pirâmide: Estudos brasileiros (pp. 31-48). Rio de Janeiro: Mauad X.

Brandão, M. M., \& Parente, J. G. (2012). Brasileiro gosta de "muvuca"? Impacto da densidade humana no comportamento de compra. Revista de Administração de Empresas, 52(6), 613-627.
Castilhos, R., \& Rossi, C. A. (2009). Subindo o morro: Consumo, posição social e distinção entre famílias de classes populares. In A. Rocha, \& J. Silva (Orgs.), Consumo na base da pirâmide: Estudos brasileiros (pp. 49-74). Rio de Janeiro: Mauad X.

Chauvel, M. A., \& Mattos, M. P. A. Z. (2008). Consumidores de baixa renda: Uma revisão dos achados de estudos feitos no Brasil. Cadernos EBAPE, 6(2), 1-17.

Chauvel, M. A., \& Suarez, M. (2009). Consumidores pobres e insatisfação pós-compra: "Eles não têm respeito pela gente". In A. Rocha, \& J. Silva (Orgs.), Consumo na Base da Pirâmide: Estudos brasileiros (pp. 179-204). Rio de Janeiro: Mauad X.

Christopoulos, P. T., \& Ferreira, C. M. G. (2012). A influência do Programa Bolsa Família sobre o comportamento de consumo da baixa renda. Administração Pública e Gestão Social, 4(2), 202220.

Costa, M. C. M., Fo. \& Motta, P. C. M. (2015). Gestão de orçamento nas compras de supermercado da nova classe média. Revista Pensamento Contemporâneo em Administração, 9(4), 111-127.

Cotlier, M. (2003, November 22). Reinventing the store. The Economist, 65-68.

D'Andre, G., Ring, L. J., Aleman, B. L., \& Stengel, A. (2006). Breaking the myths on emerging consumers in retailing. International Journal of Retailing \& Distribution Management, 34(9), 674-686.

Hair, J. F., Jr., Anderson, R. E., Tatham, R. L., \& Black, W. C. (2005). Análise multivariada de dados (5a. ed.). Porto Alegre: Bookman.

Hemais, M. W., Borelli, F. C., Casotti, L. M., \& Dias, P. I. R. C. (2014). Economics, marketing and low income individuals: Interest after a 
history if indifference. Revista de Ciências da Administração, 16(39), 49-64.

Hooley, G. J., Saunders, J. A., \& Piercy, N. F. (2005). Posicionamento competitivo. São Paulo: Atlas.

Johnson, D. S., \& Grayson, K. (2005). Cognitive and affective trust in service relationships. Journal of Business Research, 58(4), 500-507.

Limeira, V. M. T. (2008). O potencial do mercado de baixa renda. In J. G. Parente, T. M. V. Limeira, \& E. Barki (Orgs.), Varejos para a baixa renda (pp. 33-50). Porto Alegre: Bookman.

Mattoso, C. L. Q. (2010). Classes sociais, peculiaridades na base da pirâmide e a possibilidade de esquemas classificatórios. Anais do Encontro Nacional da Associaçâo Nacional de Programa de Pós-Graduação, Rio de Janeiro, RJ, Brasil, 34. Recuperado de http://www.anpad.org.br/admin/ pdf/mkt1751.pdf

Mattoso, C. L. Q., \& Rocha, A. (2009). Significado do crédito para os consumidores pobres: Identidade, distinção e dádiva. In A. Rocha, \& J. Silva (Orgs.), Consumo na Base da Pirâmide: estudos brasileiros (pp. 75-96). Rio de Janeiro: Mauad X.

Miotto, A. P., \& Parente, J. G. (2015). Retail evolution model in emerging markets: Apparel store formats in Brazil. International Journal of Retail \& Distribution Management, 43(3), 242260.

Morrison, D. G. (1969). On the interpretation of discriminant analysis. Journal of Marketing Research, 6(2), 456-463.

Neri, C. M. (Org.). (2010). A nova classe média: O lado brilhante dos Pobres. Rio de Janeiro: FGV/ CPS.

Nogami, V. K. C., \& Pacagnan, M. N. (2011). Consumo da base da pirâmide: Uma análise bibliométrica do estado da arte na produção acadêmica no Brasil. Anais do Anais do Encontro Nacional da Associação Nacional de Programa de Pós-Graduação, Rio de Janeiro, RJ, Brasil, 35. Retrieved from http://www.anpad.org.br/admin/ pdf/MKT2980.pdf

Nogami, V. K. C., Vieira, F. G. D., \& Medeiros, J. (2012). Reflexões acadêmicas e de mercado para o marketing na base da pirâmide. Revista Negócios, $17(4), 55-73$.

Parente, J. G., \& Barki, E. (2006). Varejo na baixa renda. GV executivo, 5(1), 39-43.

Parente, J. G., \& Barki, E. (2008). Valor no varejo direcionado ao segmento de baixa renda. In J. G. Parente, T. M. V. Limeira, \& E. Barki (Orgs.), Varejos para a Baixa Renda (pp. 51-65). Porto Alegre: Bookman.

Parente, J. G., Barki, E., \& Kato, H. (2005). Consumidor de baixa renda: Desvendando as motivaçôes no varejo de alimentos. Anais do Encontro Nacional da Associação Nacional de Programa de Pós-Graduação, Rio de Janeiro, RJ, Brasil, 28. Retrieved from http://www.anpad. org.br/admin/pdf/enanpad2005-mktb-0754.pdf

Parente, J. G., Brandão, M. M., Miotto, P. A., \& Plutarco, F. (2012). Polos varejistas de rua ou shopping centers? Comparando as preferências da baixa renda. Brazilian Business Review, 9(n. especial), 162-189.

Peter, J. P., \& Olson, J. C. (2009). Comportamento do consumidor e estratégia de marketing. São Paulo: McGraw-Hill.

Pfeiffer, A. M. de S., \& Maffezzolli, E. C. F. (2011). Estrutura de referência de baixa renda. Pretexto, 12(3), 9-28.

Prahalad, C. K. (2010). A riqueza na base da pirâmide: Erradicando a pobreza com lucro. Porto Alegre: Bookman. 
Prahalad, C. K., \& Hammond, A. (2002). Serving the world's poor profitably. Harvard Business Review, 80(9), 4-11.

Prahalad, C. K., \& Hart, S. L. (2002). The fortune at the bottom of the pyramid. Strategy and Business, 26, 1-14.

Rocha, A., \& Silva, J. F. (2009). Consumo da pirâmide: Um desafio empresarial. In A. Rocha, \& J. Silva (Orgs.), Consumo na Base da Pirâmide: Estudos brasileiros (pp. 19-29). Rio de Janeiro: Mauad X.
Silva, H. M. R. da, Parente, J. G., \& Kato, H. T. (2009). Segmentação da baixa renda baseada no orçamento familiar. Revista de Administração FACES Journal, 8(4), 98-114.

Terres, M. S., Santos, C. P., \& Basso, K. (2015). Antecedents of the client's trust in low-versus high-consequence decisions. Journal of Services Marketing, 29(1), 26-37.

Vieira, F. G. D., Maia, G. L., \& Silva, L. C. (2010). Comportamento do consumidor no varejo. Maringá: Sebrae.

\section{Authors:}

1. Verner Luis Antoni, Post-doctor in Management, Federal University of Rio Grande do Sul, Management School. E-mail: antoni@upf.br

2. Kenny Basso, Doctor in Management, Federal University of Rio Grande do Sul, Management School. E-mail: bassokenny@gmail.com

\section{Contribution of each author:}

\begin{tabular}{lcc}
\hline Contribution & Verner Luis Antoni & Kenny Basso \\
\hline 1. Definition of research problem & $\sqrt{ }$ \\
2. Development of hypotheses or research questions (empirical studies) & $\sqrt{ }$ \\
3. Development of theoretical propositions (theoretical Work) & \\
4. Theoretical foundation/ Literature review & $\sqrt{ }$ \\
5. Definition of methodological procedures & $\sqrt{ }$ \\
6. Data collection & $\sqrt{ }$ \\
7. Statistical analysis & & $\sqrt{ }$ \\
8. Analysis and interpretation of data & $\sqrt{ }$ \\
9. Critical revision of the manuscript & $\sqrt{ }$ \\
10. Manuscript Writing & $\sqrt{ }$ \\
\hline
\end{tabular}

